\title{
ANALISIS MAKNA VERBA TOORU, SUGIRU DAN KOERU
}

\author{
Renold \\ Program Pasca Sarjana Universitas Negeri Surabaya, \\ 3ikichi@gmail.com
}

\begin{abstract}
Abstrak: Verba tooru, sugiru, dan koeru selain merupakan kata kerja pergerakan juga merupakan kata kerja yang bersinonim bila diterjemahkan ke dalam bahasa Indonesia. Untuk membuktikan apakah ke tiga verba tesebut merupakan sinonim maka dilakukan analisis dengan teknik subtitusi antar kalimat dengan dua jenis verba yaitu:tooru「通る」dan sugiru

「過ぎる」; sugiru「過ぎる」dan koeru「超える」;koeru「超える」dan tooru「通る」. Berdasarkan hasil analisis ketiga verba tersebut diketahui bahwa; 'tooru' adalah verba yang memiliki ciri subjek mulai bergerak melewati objek dengan cara masuk kedalam objek tersebut dan berakhir setelah keluar dari objek, hal ini ditandai dengan keberadaan makna preposisi penanda tempat, 'sugiru' adalah verba yang memiliki ciri subjek bergerak tidak masuk kedalam objek melainkan hanya bergerak di samping objek tersebut, 'koeru'adalah verba yang memiliki ciri subjek bergerak melewati objek dengan cara melewati sisi sebelah atas objek.
\end{abstract}

Kata Kunci: subjek, objek, makna

\begin{abstract}
The verbs tooru, sugiru, and koeru are considered as action verbs, and they are sinonimous to each other when they are translated into Bahasa Indonesia. To approve that those three verbs are sinonimous to each other, substitutional analysis is done among sentences using two kinds of verbs distributions tooru「通る」 and sugiru「過ぎる」; sugiru「過ぎる」 and koeru「超える」; koeru「超える」 and tooru「通る」. The analysis shows that 'tooru' is a verb which has a subject characteristic of initially moving unto the object by entering into it, and ending with getting out from the object. This is signed by the preposition of place, 'sugiru' is a verb which has characteristic of moving besides the object, 'koeru' is a verb which has a subject characteristic of passing by the object on its upper leverl of the object.
\end{abstract}

Keywords: subject, object, meaning

\section{Pendahuluan}

Kajian mengenai makna dalam suatu bahasa, kalimat, maupun kata telah banyak dilakukan oleh pemerhati bahasa yang melahirkan informasi-informasi baru yang sangat penting yang dibutuhkan dalam perkembangan ilmu kebahasaan khususnya perkembangan ilmu semantik. Salah satunya adalah kajian mengenai sinonim.

Suatu kalimat dapat dikatakan bersinonim dengan kalimat lain apabila memiliki kaitan makna. Hal ini sejalan dengan apa yang dikemukakan oleh Verhaar (1983:132) mengatakan, "Sinonim adalah ungkapan (biasanya sebuah kata tetapi dapat pula frasa atau malah kalimat) yang kurang lebih sama maknanya dengan suatu ungkapan lain." Misalnya pada kata senang, gembira, dan riang, kemudian pada kata gaji, upah, bayaran, memiliki arti yang sama maka kata tersebut dikatakan bersinonim satu sama lain. 
Tarigan (2009:14) mengatakan, "Sinonim adalah kata-kata yang mengandung makna pusat yang sama, tetapi berbeda dalam nilai rasa, atau secara singkat sinonim adalah kata-kata yang mempunyai denotasi yang sama tetapi berbeda dalam konotasi."

Berdasarkan pemaparan pendapat diatas dapat diketahui bahwa sinonim adalah kata, frasa maupun kalimat yang memiliki kesamaan makna meskipun demikian dalam suatu kata, kalimat maupun frasa ada beberapa hal yang dapat menjadi perbedaan.Kesinoniman suatu bahasa dapat terjadi karena persamaan arti secara leksikal maupun gramatikal

Verba 'melewati' dalam bahasa Indonesia memiliki beberapa sinonim salsh satunya adalah; 'melalui' (KBBI, 2008: 823).Verba 'melalui' merupakan verba yang memiliki makna leksikal gerak fisik subjek yang melewati objek. Untuk lebih jelasnya perhatikan contoh berikut:

(1) ...Mata melepaskan umpan lambung melewati barisan pertahanan MU,...

(bola.kompas.com, 01/04/2013)

(2) Test drive, suspensi Xenia makin teruji saat melewati jalan berlubang

(tribunnews.co, 18/05/2013)

Pada contoh (3) dan (4) agen membutuhkan instrumen sebagai perantara. Verba 'melewati' bila disubtitusikan dengan verba 'melalui' dan 'melampaui' maka bentuk kalimatnya akan menjadi seperti berikut:

(3) ...Mata melepaskan umpan lambung

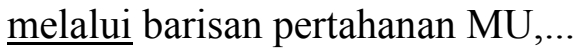

(4) ...Mata melepaskan umpan lambung melintasibarisan pertahanan MU...

(5) Test drive, suspensi Xenia makin teruji saat melalui jalan berlubang.

(6) Test drive, suspensi Xenia makin teruji saat melintasi jalan berlubang.
Pada contoh kalimat (5) dan (7) dengan menggunakan verba 'melalui' kalimat tersebut dapat berterima karena memiliki kesamaan makna pada contoh kalimat (3) dan (4), kemudian pada contoh kalimat (6) dan (8) kalimat tersebut juga berterima karena disamping konstruksi kalimat tersebut sudah benar juga kalimat tersebut memiliki kesamaan makna dengan contoh (3) dan (4).

Bahasa Jepang adalah salah satu bahasa di dunia yang sering diteliti perkembangan kebahasaannya khususnya dalam bidang semantik, hal ini disebabkan karena bahasa Jepang memiliki banyak huruf tetapi bunyi yang dihasilkan oleh huruf-huruf tersebut terkadang sama misalnya kata kaeru memiliki dua makna yaitu: pulang dan katak. Kemudian kata hashi yang memiliki tiga makna yaitu, jembatan, sumpit, dan pinggir. Untuk membedakan makna dari kata yang sama tersebut dalam bahasa Jepang digunakan huruf kanji, sementara dalam pelafalannya dibedakan dengan aksen.

Bagi pembelajar asing seperti pembelajar orang Indonesia, mereka akan mengalami kesulitan karena tidak terbiasa dengan aksen dan tidak mengenal huruf kanji sebelumnya. Selain kaya akan huruf, dalam bahasa Jepang juga banyak terdapat sinonim dan polisemi. Misalnya pada kata hiku yang apabila diartikan dalam bahasa Indonesia berartimenarik misalnya pada kalimat 「ひきだしをひく」 menarik laci, namun akan menimbulkan pertanyaan bagi pembelajar pemula bila menemukan kalimat 「ピアノをひく」 memainkan piano,「じしょをひく」membuka kamus. Sementara beberapa kata dalam bahasa Jepang bila diterjemahkan kedalam bahasa Indonesia dapat dinyatakan dengan arti melewati yaitu pada kata「通る」tooru,

「過ぎる」sugiru, 「超える」koeru. Misalnya pada kalimat berikut: 
（7）村を通る。

Mura o toru

Melewati Kampung

（8）京都を過ぎる。

Kyoto o sugiru

Melewati Kyoto

(9) 丘を越える

Oka o koeru

Melewati Bukit

(Kenji Matsuraa, 1994: 1100, $1001,515)$

Contoh(3), (4), dan (5) di atas memperlihatkan bahwa ketiga verba tersebut memiliki kesamaan arti apabila diterjemahkan kedalam bahasa Indonesia, meskipun demikian tentu saja terdapat halhal yang menjadi batasan-batasan sejauh mana ketiga verba dapat dikatakan sebagai sebuah sinonim.

Kesinoniman yang terdapat dalam bahasa Jepang menjadi suatu kajian penelitian yang menarik khususnya bagi peneliti bahasa Jepang orang Indonesia hal ini disebabkan karena beberapa verba yang diterjemahkan ke dalam bahasa Indonesia memiliki arti yang sama hal ini tampak dalam beberapa penilitian yang telah dilakukan mengangkat tema sinonim dalam bahasa Jepang yaitu; Penelitian oleh Sutedi (2004), pengajar Universitas Pendidikan Indonesia meneliti verba oriru, kudaru, sagaru, dan furu yang bila diterjemahkan kedalam bahasa Indonesia berarti 'turun'. Kemudian oleh Sawiah (2009), mahasiswa S1 Universitas Pendidikan Indonesia yang meneliti verba tasukeru dan tetsudau, apabila diterjemahkan kedalam bahasa Indonesia berarti 'menolong/ membantu', serta penelitian oleh Yusup (2011) meneliti verba okoru dan shikaru yang apabila diterjemahkan kedalam bahasa Indonesia berarti 'marah'.
Berdasarkan pemaparan di atas maka dalam tulisan ini akan di uraikan verba 「通る」tooru，「過ぎる」sugiru，「超え る」koeru dapat dikatakan sebagai sebuah sinonim dan perbedaan apa yang terdapat pada masing-masing ketiga verba tersebut.Untuk menganalisis ketiga verba tersebut digunakan konsep semantik dari Leech dan teknik substitusi.

Leech (2003:

menggunakan analisis komponen makna, yaitu proses memilah-milahkan pengertian suatu kata ke dalam ciri-ciri khusus minimalnya; yaitu, ke dalam komponen yang kontras dengan komponen lain. Rumus-rumus ini disebut sebagai definisi komponensial atau lebih dikenal dengan analisis komponen. Dengan menggunakan rumus seperti ini, kita dapat menunjukkan sinonimi dari dua kata dengan menggunakan definisi komponensial yang sama.

Sejalan dengan pendapat di atas, Sutedi(2003:121-123) menggunakan beberapa teknik dalam menentukan suatu sinonim yang terdapat dalam suatu kata, frasa atau kalimat:

1. Menentukan objek yang diteliti.

2. Mencari literatur yang relevan.

3. Mengumpulkan semua jitsurei 「実 例」'contoh kongkrit'.

4. Mengklasifikasi setiapjitsurei「実例」 tersebut.

5. Membuat pasangan kata yang akan dianalisis

6. Melakukan analisis

7. Membuat kesimpilan atau generalisasi

Berdasarkan pemaparan teori diatas maka, untuk menganalisis verba「通る」 tooru, 「過ぎる」sugiru, 「超える」koeru digunakan teknik subtitusi, teknik subtitusi adalah kegiatan mengganti kata yang dianggap sama dalam suatu kalimat kemudian mencocokkan apakah kalimat tersebut masih memiliki makna yang sama atau tidak.Penulis juga melakukan 
wawancara langsung kepada penutur asli bahasa Jepang yaitu Mr. Matsumoto dari Japan Foundation untuk mengetahui apakah ke tiga verba tersebut apabila saling bersubtitusi masih memenuhi kaidah dalam taha bahasa Jepang. Hal ini sesuai dengan pendapat Momiyama (dalam Sutedi, 2003: 120) yang menyatakah bahwa salah satu cara mengidentifikasi sinonim adalah dengan cara chokkanteki atau secara intuitif langsung terhadap penutur asli. Sumber data yang digunakan adalah koran online Asahi Shinbun dan MainichiShinbun,serta kamus online sebagai bahan perbandingan kalimat

\section{Pembahasan}

Untuk menganalisis tiga verba tooru 「通る」,sugiru「過ぎる」, dan koeru 「超える」 sebagai suatu sinonim maka akan diuraikan beberapa contoh penggunaan ketiga verba tersebut dalam beberapa kalimat untuk mengetahui beberapa makna yang terkandung di dalamnya, kemudian melakukan subtitusi antar kalimat, teknik subtitusisasi dilakukan dengan menganalisis tiap dua jenis verba yaitu: tooru「通る」 dansugiru「過ぎ る」; sugiru「過ぎる」 dankoeru「超え る」; koeru「超える」dantooru「通る」. Analisis makna sinonim pada ketiga verba tersebut hanya pada makna leksikal saja atau makna sebenarnya yaitu gerak secara fisik saja. Sedangkan sinonim dengan makna kiasan seperti pada kalimat berikut tidak dibahas
(10) *彼は試験に通った。
Kare wa shiken ni tootta
$\mathrm{Dia} / / \mathrm{ujian} / / \mathrm{V}$ melewati
'dia lulus ujian'

(tangorin.com)

\section{A. Analisis Makna Verba}

1. Verba tooru「通る」

Verba ini bila diartikan kedalam bahasa Indonesia berarti 'melewati', tetapi terdapat beberapa hal yang menjadi ciri verba ini, untuk lebih jelasnya perhatikan contoh berikut:

(11) 船は橋の下を通った。

Fune wa hashi no shita o totta.

Kapal//jembatan bawah//Vmelewati

'kapal melewati bawah jembatan/

(tangorin.com)

（12）世界最小 0.75 ミリ、針穴も通る本、 凸版印刷が製作。

Sekai saisho 0,75miri, hari ana mo tooru hon, toppan insatsu ga saisaku

Terkecil di dunia/ 0,75 milimeter/ jarum/lubang pun/ Vmelewati/ percetakan toppan/ yang memproduksi

'percetakan toppan memproduksi buku (berisi gambar jenis jenis bunga dalam empat musim) yang terkecil di dunia hanya sebesar 0,75 mili mampu melewati lubang jarum sekalipun'

(asahi.com, 26/05/2013 : 1)

(13) 新幹線が通っていない北海道で...。 Shinkansen ga totte inai Hokkaido de...

Shinkansen/V tidak melewati/ / Hokkaido 'Shinkansen yang (rutenya) tidak melewati Hokkaido...'.

(asahi.com, 26/05/2013:1)

Berdasrkan ke tiga contoh kalimat di atas, di ketahui subjek pada verba tooru 「通る」 bergerak melewati objek dengan cara masuk ke dalam objek tersebut hal ini diketahui dengan mencermati makna kalimat tersebut dimana ke tiga kalimat tersebut mempunyai makna preposisi penanda tempat yang tampak maupun tak nampak pada objek. Verba tooru bila diilustrasikan pergerakannya maka akan tampak sebagai berikut: 


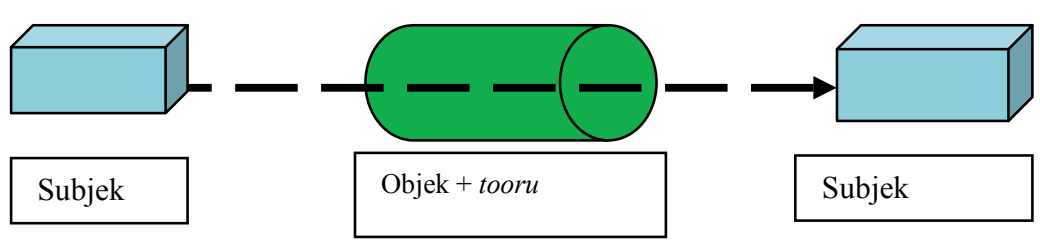

2. Verba sugiru「過ぎる」

Verba ini bila diartikan kedalam bahasa Indonesia berarti 'melewati', tetapi terdapat beberapa hal yang menjadi ciri verba ini, untuk lebih jelasnya perhatikan contoh berikut:

(14) 列車は京都駅を過ぎた。

Ressha wa kyotoeki wo sugita

Kereta//kyoto stasiun//Vtelah melewati

'kereta telah melewati stasiun kyoto'

(dictionary.goo.ne.jp)

(15) $15 \mathrm{~km}$ 過ぎの品川ではランナーた ちが続々と折り返し。

Jugoichikirometooru sugi no shinagawa dewa ranna tachi ga zokuzoku oritachi.

$15 \mathrm{~km} /$ Vmelewati $/$ shinagawa $/$ para pelari/ saling bersusulan

"para pelari saling

bersusulanmelewati kilometer $15 \mathrm{di}$

Shinagawa' (nhk.or.jp/run, 24/03/2013: 14)

（16）しかし ...30km を過ぎて脚の痛み が悪化。

Shikashi sanju kirometoru o sugite ashi no itami ga akka

Tetapi

$\mathrm{km} /$ Vmelewati/kaki/sakit/memburuk

'tetapi, kaki bertambah sakit ketika

melewati kilometer 30

(nhk.or.jp/run, 24/03/2013: 22)

Berdasarkan contoh kalimat (14), (15) dan (16) diketahui bahwa subjek bergerak melewati objek tanpa masuk ke dalam objek tersebut hal ini tampak pada contoh kalimat (14) dan (15) dimana tidak tampak adanya makna preposisi penanda tempat pada ke tiga kalimat tersebut. Verba sugiru bila diilustrasikan pergerakannya maka akan tampak sebagai berikut:

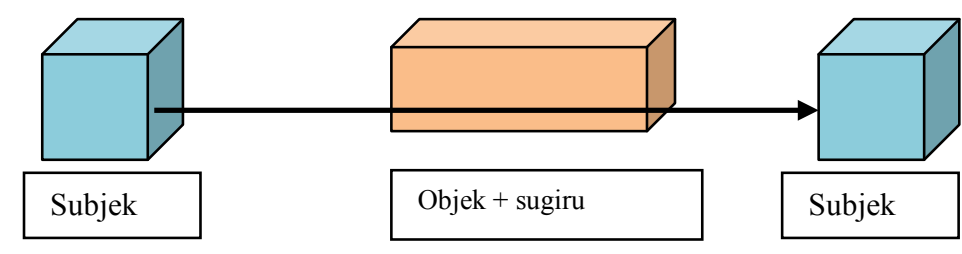

\section{Verba koeru「超える」}

Verba ini bila diartikan kedalam bahasa Indonesia berarti 'melewati', tetapi terdapat beberapa hal yang menjadi ciri verba ini, untuk lebih jelasnya perhatikan contoh berikut:
(17) 水は堤防を越えた。 Mizu wa teibou o koeta Air/tanggul/V telah melewati 'air telah melewati tanggul'

(18) 川が土手を越えてあふれた。 Kawa ga dote o koete afureta 
Sungai/tepi sungai/ V melewati dan telah meluap

'(volume) air telah meluap melewati tepi sungai'

(tangorin.com)

（19）打球は前進守備の外野手の頭上を 越えて左中間へ転がった。

Dakkyu wa zenshinshubi no gaikyuushu no zujo o koete sachukan e korogatta.

Bola(yangdipukul)/bagian

pertahanan/gelandang luar/kepala/Vmelewati/ antara tengah kanan/telah jatuh

'bola (yang dipukul) meluncur melewati kepala gelandang bertahan luar dan jatuh di sebelah tengah kanan lapangan'

(asahi.com, 29/05/2013: 3)

(20) 県警によると、車は高さ 20 セン チの縁石を越えて歩道に乗り上 げ,,..
Kenkei ni yoruto, kuruma wa takasa 20 senchi no ishiseki o koete sodou ni noriage,...

Polisi perfektur setempat/menurut/ mobil / tingginya/ $20 \mathrm{~cm} /$ pembatas jalan / Vmelewati/ trotoar/naik

'menurut polisi setempat, mobil (tersebut) naik sampai ke trotoar dan melewati pembatas jalan yang tingginya $20 \mathrm{~cm}$ '

(asahi.com, 30/05/2013: 11)

Berdasarkan contoh kalimat di atas diketahui bahwa subjek pada verba koerubergerak melewati objek dengan cara melewati sisi sebelah atas objek. Pernyataan ini sesuai dengan contoh pada kalimat (17), (18), (19) dan (20).Verba sugiru bila diilustrasikan pergerakannya maka akan tampak sebagai berikut:

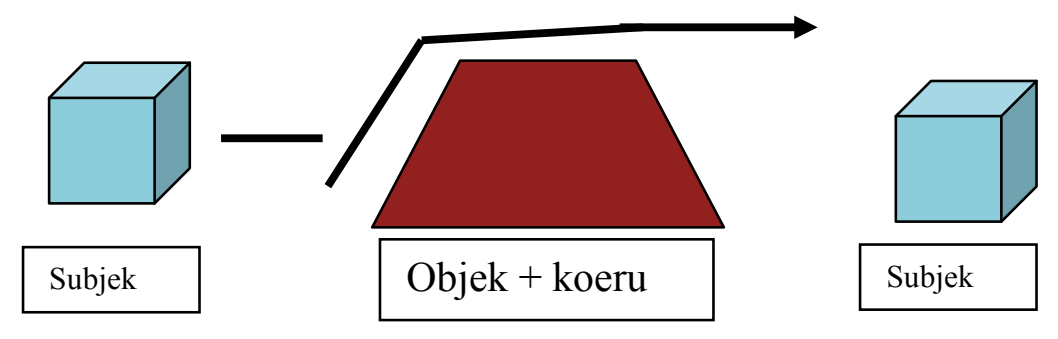

\section{B. Subtitusi Verba}

1. Subtitusi verba tooru「通る」dan sugiru「過ぎる」

(21) 船は橋の下を(通った/過ぎる)。

(22) 世界最小 0.75 ミリ、針穴も(通 る/過ぎる)本、凸版印刷が製作。

(23) 新幹線が通って/過ぎていない北 海道で...。

Subtitusi padakalimat (21), (22) dan (23)masih bisa digunakan dan masih benar secara gramatikal namun secara pemaknaan kurang tepat mengingat pada verba tooru pada contoh (11), (12) dan
(13) mensyaratkan adanya makna preposisi objek. Sementara pada analisis (14) (15) dan (16) diketahui pergerakan verba sugiru tidak menyentuh objek.

2. Subtitusi Verba sugiru「過ぎる」 dankoeru「超える」

(24) 列車は京都駅を(過ぎた/ 越えた)。

(25) $15 \mathrm{~km}$ (過ぎ/ 越え)の品川ではラン ナーたちが続々と折り返し。

（26）しかし...30km を(過ぎて/ 越えて) 脚の痛みが悪化。

Subtitusi pada kalimat (24), (25) dan (26) masih bisa digunakan dan masih 
berterima secara gramatikal, tetapi kurang tepat penggunaaanya mengingat pada verba sugiru pada contoh (14), (15) dan (16) tidak memerlukan preposisi penanda tempat yang menjadi ciri verba tersebut. Sementara diketahui pada contoh (17), (18), (19) dan (20) verba koeru menyiratkan posisi pergerakan subjek melewati sebelah atas objek.

3. Subtitusi Verba koeru「超える」 dantooru「通る」

（27）水は堤防を(越えた./通った)。

(28) 川が土手を(越えて / 通って)女ふ れた。

打球は前進守備の外野手 の頭上を(越えて/ 通って)左中間 へ転がった。

$$
\begin{aligned}
& \text { 県警によると、車は高さ } \\
& 20 \text { センチの縁石を(越えて/通っ } \\
& \text { て)歩道に乗り上げ,... }
\end{aligned}
$$

Subtitusi pada kalimat (27), (28), (29) dan (30) masih bisa digunakan dan masih berterima secara gramatikal, tetapi kurang tepat penggunaaanya mengingat pada verba koeru pada contoh (17), (18), (19) dan (20) menyiratkan posisi pergerakan subjek melewati sebelah atas objek. Sementara verba tooru mensyaratkan adanya makna preposisi penanda tempat dimana subjek bergerak kedalam objek dan berakhir setelah melewati objek, seperti yang tampak pada contoh (12) dan (13).

\section{Penutup}

Dari hasil analisis tentang sinonim verba「通る」tooru,「過ぎる」sugiru, 「超える」koeru dapat disimpulkan bahwa ketiga verba tersebut dalam bahasa Indonesia dapat diartikan dengan 'melewati', tetapi ketiga verba tersebut memiliki ciri masing masing yaitu:

1. Verba「通る」tooru

Subjek bergerak dengan cara masuk ke dalam objek dan berakhir setelah keluar dari objek.

2. Verba「過ぎる」sugiru

Verba sugiru subjek bergerak tanpa menyentuh objek hanya melewati sisi objek saja.

3. Verba「超える」koeru

Verba koeru subjek bergerak dengan cara melewati sisi atas objek.

Ketiga verba tersebut apabila saling bersubtitusi masih berterima secara gramatikal, namun secara pemaknaan tidak tepat. Hal ini disebabkan adanya persyaratan masing masing verba terhadap objeknya.

\section{Daftar Pustaka}

Leech, Geoffery. 2003.Semantik.

Yogyakarta:Pustaka Pelajar

Matsuraa, Kenji. 1994. Kamus Jepang Indonesia.Jakarta: Gramedia

Muniah, Dad, dkk. 2000. Kesinoniman

Dalam Bahasa Indonesia. Jakarta:

Pusat Bahasa, Depertemen

Pendidikan Nasional

Pateda, Mansoer. 2001. Semantik Leksikal. Jakarta: Rineka Cipta

Sutedi, Dedi. 2003. Dasar-dasar Linguistik Bahasa Jepang. Bandung: Humaniora Utama Press -. 2004. 'Turun' dalam Verba Bahasa Jepang. Bandung: Jurnal Pendidikan Bahasa Jepang Di Indonesia, Edisi Juni No. 3 hal 3257.

Tarigan, Henry Guntur. 2009. Pengajaran Semantik. Bandung: Penerbit Angkasa.

Ullman, Stephen. 2007. Semantik, Pengantar. Yogyakarta: Pustaka Pelajar 